\title{
The Special Tribunal for Lebanon (STL): Selective Justice and Political Maneuvers
}

\author{
Omar Nashabe*
}

Al-Akhbar Research Unit - Beirut, Lebanon

\begin{abstract}
The Special Tribunal for Lebanon is the most recently established international criminal tribunal. It was created by the UN Security Council in 2007 to prosecute those responsible for the assassination of former Prime Minister Rafik Hariri and others in 2005. However, the process of creating the tribunal did not comply with Lebanese Constitutional provisions. This paper sheds light on the politics of selective justice, recalling impunity in Lebanon before and after Hariri's assassination. It also exposes the UN Security Council's double standards and argues that by creating the tribunal under Chapter VII of the UN Charter, Lebanon's sovereignty was compromised.

The international criminal investigation leading to the recent indictment seemed also highly controversial. The political motivations behind the Special Tribunal's standards are exposed in this paper, whereas numerous breaches of local legal provisions, ethics and confidentiality are shown. The paper concludes with a discussion of suggested remedies.
\end{abstract}

Keywords: Special Tribunal for Lebanon, Lebanon, Rafic Hariri, Terrorism, Selective justice, Hezbollah, Israel.

\section{INTRODUCTION}

On February 14, 2005, Valentine's Day, at 12:56 PM a massive explosion on Beirut's Mediterranean coastline took the life of former Lebanese Prime Minister Rafik Hariri and 22 people who were accompanying him or happened to be at the site of the blast. The explosion also injured 231 persons and damaged public and private property in a 500-meter radius. Forensic examination of the explosion indicated that the equivalent of 2,500 kilograms of TNT (trinitrotoluene) was detonated by a suicide bomber using an improvised explosive device (IED) from inside a Mitsubishi van close to the convoy transporting Hariri along the sea road from the Parliament in Beirut's Downtown district to his residence in the city ${ }^{1}$. Among the dead were several of Hariri's bodyguards, former Minister of the Economy Bassel Fleihan ${ }^{2}$, bystanders who happened to be walking on the beach front at the fateful time, and several Syrian workers in a nearby construction site.

The United Nations Security Council reacted immediately to the assassination, condemning it as a "terrorist act" and sending a fact-finding mission to

*Address corresponding to this author at the Al-Akhbar Research Unit - Beirut, Lebanon; Tel: +9611759500 ext. 325; Fax: +9611759597;

E-mails: onashabe@al-akhbar.com, omarnashabe@windowslive.com

\footnotetext{
'Bellemare, D. (10 June 2011) Indictment, The Prosecutor v/s Mustapha Amine Badreddine et al. Special Tribunal for Lebanon. Para, 51 Page 20.

${ }^{2}$ Despite being seated beside Hariri when the explosion occurred, Fleihan lived through the February 14 explosion; however, severe burns covered over $95 \%$ of his body. Fleihan was airlifted to Percy Military Hospital in Clamart (suburb of Paris), where he survived for 64 days before he passed away on April 18, 2005
}

E-ISSN: 1929-4409/12
Beirut. Within two months, the UNSC had set up a formal UN investigation commission amidst strong, though unsubstantiated accusations pointing to elements within the Syrian regime-in collusion with their Lebanese allies within the security establishment-as the culprits. With the political and security situation extremely tense in Lebanon, and the state effectively split, the UNSC in 2007authorized the establishment of the Special Tribunal for Lebanon (STL) based in the Hague. On January 17, 2011, after more than 5 years of international criminal investigations, the Prosecutor of the Special Tribunal for Lebanon (STL) Daniel Bellemare filed a confidential indictment to the pre-trial judge Daniel Fransen, initially accusing four members of Hezbollah of involvement in the assassination of Hariri. The first and so far the only indictment in this case was published, after it was confidentially amended at the request of Pre-trial Judge Daniel Fransen, on August 17, $2011^{3}$.

According to the UNSC, the STL is allegedly aimed at ending impunity in Lebanon and its operation was to be "based on the highest international standards of criminal justice." Yet, several structural and procedural problems associated with the STL and the political context indicate that these contentions are deeply problematic.

This paper thus offers a critique of the history, structure and procedures of the international criminal investigation and the establishment of the STL. Its

\footnotetext{
${ }^{3}$ The indictment filed by Prosecutor Daniel Bellemare on January 17, 2011 was amended twice before it was confirmed by Pre-Trial Judge Daniel Fransen on June 28, 2011, first on March 11, 2011, then on May 6, 2011.
} 
central arguments are that: (1) launching an international criminal investigation in the Hariri case was politicized and highly selective in light of the history of political assassinations in Lebanon; (2) the establishment of the STL does not comply with the Lebanon's Constitution, undermining Lebanon's sovereignty; and (3) the standards of the international criminal investigation and the STL were set to fulfill political purposes. It concludes that while these problems have thus undermined the original calls for justice and the ending of impunity in Lebanon, even leading to further division and violence, there are still steps that can be taken to serve the cause of international justice for Hariri while also protecting state institutions and the political process in Lebanon.

\section{THE POLITICS OF SELECTIVE JUSTICE: WHY THE STL NOW?}

Political assassinations are not new to Lebanon ${ }^{4}$. Riad El-Solh, the first post-independence prime minister, was assassinated in 1951. This was followed by a series of assassinations targeting politicians, journalists and religious leaders. The list includes members of parliament Naim Moghabghab (1960), Maarouf Saad (1975), Tony Frangieh, his wife and daughter and 30 others $(1978$,$) , Kamal Joumblatt$ (1977), Nazem El-Kadri (1989), Elie Hobeika (2002) and Dany Chamoun, his wife and their two children (1990). Mufti Sheikh Hassan Khalid (1989), Sheikh Sobhi Saleh (1986), Sheikh Ahmad Assaf (1987), Imam Hassan Al-Shirazi (1980), Sheikh Halim Taqieddine (1987) and Sheikh Nizar Halabi (1995) were also assassinated. In 1978, Imam Mousa Sadr, disappeared with two companions, journalist Abbas Badred-dine and Sheikh Mohamad Yakoub, while they were in Libya.

President-elect, Bashir Gemayel was assassinated in 1982 (14 September) and President Rene Muawad was assassinated on Independence Day (November 22) 1989 , while an attempt was made on the life of former president Camille Chamoun back in 1980.

\footnotetext{
${ }^{4}$ Haven et. Al, defines political assassinations as "deliberate, extralegal killings of individuals for political purposes" Haven, M.C., Leiden C. \& Schmitt, K. M (1970) The Politics of Assassination (Englewood Cliffs, NJ: Prentice Hall) page 4. However, according to Bosco (2009), debates over the assassination of Rafik Hariri reflect fundamental differences on the meaning and definition of political assassination.(Bosco, R.M. (2009), The Assassination of Rafik Hariri: Foreign Policy Perspectives. International Political Science Review, Vol. 30, No. 4, 349-361. Page 359). Ben-Yehuda (1997) further claims that the characterization of an event as a political assassination, an execution, or an act of terror is always a political, social and cultural construction. (Ben-Yehuda, N. (1997). Political Assassination Events as a Cross-Cultural Form of Alternative Justice. International Journal of Comparative Sociology 38(1-2): 25-47. Page 28).
}

Prime Minister Rashid Karameh, was assassinated in 1987, and an attempt was made on the life of another Prime Minister, Salim al-Hoss in 1984.

Several religious leaders were assassinated ${ }^{5}$, while foreign diplomats including an American ambassador, French, Iraqi and Jordanian diplomats, and the president of the American University of Beirut were all murdered.

Indeed, the assassination of Hariri was also followed by a series of assassinations including those of MP Gebran Tueini, politician George Hawi and journalist Samir Kassir in 2005; Minister Pierre Gemayel and activists Mohammad and Nidal Majzoub in 2006; MPs Walid Eido and Antoine Ghanem and Army General Francois Hajj in 2007; police investigator Wissam Eid in 2008 and his superior General Wissam El-Hassan in 2012. This period also witnessed, in the summer of 2006, Israel's sixth invasion of Lebanon in which over a thousand civilians were killed and many thousands more injured.

All of the assassinations listed above and numerous other serious crimes committed in Lebanon since 1975 have either gone unresolved, unpunished ${ }^{6}$, or were whitewashed by amnesty laws and international silence. To be sure, this appalling record does not, in of itself, make the assassination of Hariri less deserving of proper investigation and fair punishment for the perpetrators. But this paper suggests that the legal and moral basis for pursuing justice in the Hariri case while refraining from doing so in many of these other cases is not a coincidence and is thus seriously problematic as it reflects the politics of selective justice. The STL jurisdiction, after all, is explicitly limited to the Hariri assassination and other related assassinations. This selective approach to access to justice is further analyzed on two levels: on the international level, where the UN Security Council used double standards in reacting to mass murder, atrocities and political assassinations in Lebanon and elsewhere; and on the local level, where amnesty laws and "particular pardons" were granted in previous assassinations of similar gravity.

In the same way dominant groups in society often use the law as a way of maintaining their dominance over subordinate groups, it may be inferred that the

${ }^{6}$ Knudsen, A. (2010), Acquiescence to Assassinations in Post-Civil War Lebanon? Mediterranean Politics, Vol. 15, No. 1, 1-23. 
Security Council used its powers under Chapter seven of the UN Charter to maintain its dominance over Lebanon. Marxist theory may further suppose that the Security Council reacted to the murder of Rafik Hariri by actively supporting the creation of an international tribunal, because he was one of the richest people in the World ${ }^{7}$, whereas the council did not actively react to numerous other crimes because the victims of such crimes were persons whose wealth and power cannot be compared with Hariri's wealth and power. This for Marx one of the main functions of law is to respond to power relationships. This also applies to UN Security Council Resolutions. The "legal superstructure", according to Pashukanis, exists and functions because behind it "stands an organization of the ruling class, namely the apparatus of coercion and power". This does not mean that the Security Council has to use force in every case. "Much is achieved by simple threat, by the knowledge of helplessness and of the futility of struggle, by economic pressure, and finally by the fact that the working classes are in the ideological captivity of the exploiters"

\section{UNSC's Internationalization of an Assassination}

The United Nations Security Council reaction to Hariri's assassination differed from its reaction to an assassination which occurred during the same period, and which was similar to Hariri's assassination in terms of modus operandi, background and circumstances. This supports the argument that the UNSC's selective intervention and its decisions on what constitutes threats to international peace and security is politically motivated and that the Security Council's resolutions' reference to judicial arguments to establish the UNIIIC and the STL is inadequate.

Former Pakistani Prime Minister Mohtarma Benazir Bhutto was assassinated on December 27, 2007. The President of the Security Council issued a statement condemning "in the strongest terms the terrorist suicide attack" against Bhutto, but did not request the Secretary-General "to follow closely the situation ... and to report urgently on the circumstances, causes and consequences of this terrorist act" as was the case

\footnotetext{
${ }^{7}$ Rafik Hariri ranked 108 in the 2004 Forbes Magazine's Richest People with a fortune exceeding U\$ 4 Billion http://www.forbes.com/2004/02/25/ bill04land.html

${ }^{8}$ Marksistskaia teoriia gosudarstva $i$ prava, pp.9-44 in E. B. Pashukanis (ed.), Uchenie o gosudarstve i prave (1932), Partiinoe Izd., Moscow. From Evgeny Pashukanis, Selected Writings on Marxism and Law (eds. P. Beirne \& R. Sharlet), London \& New York 1980, pp.273-301. Translated by Peter B. Maggs.
}

for PM Hariri's assassination ${ }^{9}$. The UN Secretary General Kofi Annan dispatched a fact-finding mission to Beirut. The mission, headed by Peter Fitzgerald, an Irish deputy police Commissioner, arrived in the Lebanese capital on February 25. During a period of less than one month, the mission met Lebanese officials and politicians, from both the government and opposition, studied the Lebanese investigation and legal proceedings, examined the crime scene, collected evidence, and interviewed witnesses, and reported that "accusations and counter-accusations are rife and aggravate the ongoing political polarization"10. Based on Fitzgerald's recommendation to launch an international criminal investigation in the Hariri case, the Security Council passed Resolution 1595 on April 7, 2005, ordering the establishment of a United Nations International Independent Commission (UNIIIC) which was later granted Chapter VII powers ${ }^{11}$, to help identify the "perpetrators, sponsors, organizers and accomplices" $^{12}$ of the February 14, 2005 terrorist attack. Chapter VII of the UN Charter allows the Council to "determine the existence of any threat to the peace, breach of the peace, or act of aggression" and to take military and nonmilitary action to "restore international peace and security".

In contrast with the Hariri case, more than one year after the assassination of Bhutto, in February 2009, the UN Secretary General established an "international commission" that "should be fact-finding in nature"13. Unlike the Lebanon case, the international commission was established following the request of the Government of Pakistan five months after the assassination (in May 2008), "and after extensive discussions with Pakistani authorities"14. In the Bhutto case, the UN Secretary General clearly noted in an official letter to the President of the Security Council that the commission's mandate would be for a duration of six months (starting on July 1, 2009) that was extended for a further 3 months period ending in March $2010^{15}$. This again is in contrast with UN "fact finding"

\footnotetext{
${ }^{9}$ http://daccess-dds-ny.un.org/doc/UNDOC/GEN/N07/660/13/PDF/N0766013. pdf?OpenElement

${ }^{0}$ Report of the Fact-finding Mission to Lebanon inquiring into the causes, circumstances and consequences of the assassination of former Prime Minister Rafik Hariri http://domino.un.org/unispal.nsf/0/79cd8aaa858fdd2d 85256fd500536047? OpenDocument

${ }^{11}$ UN Security Council Resolution 1644, December 15, 2005.

${ }^{12}$ S/RES/1595(2005) http://daccess-ods.un.org/access.nsf/Get?OpenAgent\& $\mathrm{DS}=\mathrm{s} / \mathrm{res} / 1595(2005) \&$ Lang=E

${ }^{13}$ Letter of UN Secretary General Ban Ki-moon to the President of the Security Council dated February 3, 2009. S $\ 2009167$ http://daccess-dds-ny.un.org/doc/ UNDOC/GEN/N09/226/66/PDF/N0922666.pdf?OpenElement

${ }^{14}$ Ibid.

${ }^{15}$ UN Secretary General letter to the President of the Security Counci requesting a three month extension for the Bhutto commission http://daccessdds-ny.un.org/doc/UNDOC/GEN/N10/203/03/PDF/N1020303.pdf?Open Element
} 
in the Hariri assassination that lasted just one month. Also, unlike the Hariri case, the UN Secretary General clearly noted that in the Bhutto assassination case, that "the duty of determining criminal responsibility of the perpetrators of the assassination would remain with the Pakistani authorities"16. In the Hariri assassination case, such duty was assigned to an international tribunal established without the formal consent of Lebanese authorities, as will be explained later in this paper.

On March 29, 2006 the Security Council passed Resolution 1664 launching the first step towards creating an international tribunal to identify and bring to justice all those responsible for the "terrorist" bombing that killed Lebanese Prime Minister Rafik Hariri and others. It requested Secretary-General Kofi Annan to negotiate an agreement with the Lebanese Government "aimed at establishing a tribunal of an international character based on the highest international standards of criminal justice" ${ }^{17}$. The jurisdiction of the STL held a central part of the negotiations that followed. The mandate ${ }^{18}$ of the Special Tribunal is limited to investigating and then prosecuting the perpetrators of the "terrorist" assassination of Hariri and 22 others. It has jurisdiction over other assassinations and assassination attempts committed between 1 October 2004 and 12 December $2005^{19}$, i.e. the attempted assassination of Marwan Hamade (October 1, 2004) and the assassination of Samir Kassir (June 2, 2005), George Hawi (June 21, 2005) and Gebran Tueini (December 12, 2005), only if the STL finds them to be connected ${ }^{20}$ to the assassination of Hariri and of a similar nature and gravity. Thus, unlike previous international tribunals established to try massive violations of international law, such as the International Criminal Tribunal for Former Yugoslavia or the International Criminal Tribunal for Rwanda, the primary mandate of the STL relates to a single attack, with only the possibility of trying selected others ${ }^{21}$.

\footnotetext{
${ }^{16}$ Ibid.

${ }^{17}$ Security Council Resolution 1664 March 29, 2006 http://daccess-ddsny.un.org/doc/UNDOC/GEN/N06/290/16/PDF/N0629016.pdf?OpenElement

${ }^{18}$ defined by Article 1 of the STL Statute (Annex Resolution 1757)

${ }^{19}$ or a later date to be determined by the UN and Lebanon with the consent of the Security Council

${ }^{20}$ The factors which may determine such a connection include, according to Article 1, "a combination of the following elements: criminal intent (motive), the purpose behind the attacks, the nature of the victims targeted, the pattern of the attacks (modus operandi) and the perpetrators".

${ }^{21}$ Bouhabib, M. A. (2010) Power and Perception: The Special Tribunal for Lebanon. Berkeley Journal of Middle Eastern Islamic Law. Vol. 3 No.1, 173-20. Page 190
}

In fact, the time frame of the STL's mandate was itself a highly selective and politicized affair. A UN official participating in the negotiations to establish the STL indicated that its jurisdictional limitations were included in its mandate "at the behest of the United States to ensure that the Tribunal could not take jurisdiction over the conduct of Israeli forces during the 2006 conflict between Israel and Hezbollah/Lebanon"22.

Another sign of the UNSC's selective reactions to access to justice appeared a few months after the Hariri assassination. The Security Council, after 15 days of silence over the continuous killings in 2006, had merely expressed "its deep concern for Lebanese and Israeli civilian casualties" ${ }^{23}$, and unlike its immediate reaction to the February 14 murder of Hariri and 22 others in 2005, there was no request from the Secretary General "to follow closely the situation in Lebanon and to report urgently on the circumstances, causes and consequences" as was the case on February 15.

Overall, the mandate of the STL is, by far, the narrowest of any other international tribunal to date. In comparison with the 1993 International Criminal Tribunal for the former Yugoslavia's mandate which consisted of bringing to justice those responsible for serious violations of international humanitarian law committed in the former Yugoslavia since 1991, the Special Tribunal for Lebanon has no jurisdiction to address serious crimes and human rights violations committed against thousands in Lebanon in recent years or decades ${ }^{24}$. In Lebanon, families of thousands of persons who disappeared during the war question the creation of the STL to investigate the killings of a few elites with no serious investigations into the fate of their relatives ${ }^{25}$. In fact, the establishment of the STL is viewed by many in Lebanon more motivated by politics

\footnotetext{
${ }^{22}$ Cerone, J. (2009) US Attitudes toward International Criminal Courts and Tribunals, in The Sword and the Scales, Edited by Romano, C., New York: Cambridge University Press, page179.

${ }^{23}$ Security Council Presidential Statement. S/PRST/2006/34. July 27, 2006 http://daccess-dds-ny.un.org/doc/UNDOC/GEN/N06/447/65/PDF/N0644765. pdf?OpenElement

${ }^{24}$ According to Knudsen, "The 15-year-long civil war (1975-90) was extremely bloody, with atrocities and massacres committed by all sides to the conflict. The war inflicted physical damage estimated at U\$25 Billion, more than halved the country's GDP, caused massive human suffering, including more than 150,000 deaths, displaced some 800,000 people and increased emigration from the country (...) more than 3,600 car bombs killed close to 4,500 people" Knudsen A. (2010) Acquiescence to Assassinations in Post-Civil War Lebanon? Mediterranean Politics, Vol. 15, No. 1, 1-23. Page 7-8

${ }^{25}$ Sriram, C. (2010). Unfinished Business: Peace building, Accountability, and Rule of Law in Lebanon. SOAS School of Law Legal Studies Research Paper Series. Research Paper No.16/2010. Page 12.
} 
than by the desire to pursue justice or confront a broader culture of impunity ${ }^{26}$.

\section{No End to Impunity: Lebanon's Amnesty for Assassinations and Wartime Atrocities}

One of the main arguments in favor of establishing the STL was Lebanon's desire to end impunity, yet the record of the post-civil war period (1990-2005) shows clearly that Lebanon's politicians had no serious will to hold those responsible of wartime atrocities and political assassinations accountable. No special judicial body was created to prosecute those responsible of wartime atrocities and the perpetrators were pardoned by an amnesty law. Several warlords became Members of Parliament and high ranking government officials. This confirms Marxist interpretation of law and the functioning of the judicial system.

Impunity from prosecution in Lebanon was fostered by amnesty laws. The Lebanese Constitution (Article 53 Paragraph 9) allows the President to grant "particular pardons" and empowers the Government and the parliament to vote general amnesty laws. Since independence in 1943, every Lebanese president and almost every cabinet and parliament granted amnesty to hundreds and perhaps thousands of presumed criminals $^{27}$.

Indeed, an amnesty law was passed on July 18, 2005, just five months after the assassination of Hariri, by a parliament elected in May 2005 dominated by Hariri's political allies. It amnestied ex-warlord ${ }^{28}$ Samir Geagea, for five specific sentences against him. In one of those cases, Geagea was convicted and sentenced by The Judicial Council (the highest Lebanese judicial authority) for the assassination of Prime Minister Rashid Karameh in 1987. The fact that Karameh and others were assassinated during the civil war does not make their cases less deserving of prosecution.

\footnotetext{
${ }^{26}$ Wierda, M., Nassar, H. \& Maalouf, L. (2007). Early Reflections on Local Perceptions, Legitimacy, and Legacy of The Special Tribunal for Lebanon. Journal of International Criminal Justice. Vol. 5 No.5. pp.1065-1081.

${ }^{27}$ General amnesties issued since independence include The general amnesty of October 19, 1949 which was issued for crimes committed before 12 September 1949; the general amnesty of August 31, 1951 which was issued for all crimes related to general elections; the general amnesty of December 24 , 1958, which was issued for all crimes of a political nature and acts of rebellion and infraction of state security committed before October 15, 1958; a similar amnesty was issued on February 17, 1969, for acts committed before January 1, 1967; another similar amnesty was issued on 26 August 1991 for acts committed before March 28, 1991. A general amnesty for all drug-related crimes committed before December 31, 1995 was issued by Law No. 666 of December 19, 1997.

${ }^{28}$ Amnesty for Lebanese ex-warlord, BBC, July 18, 2005 http://news.bbc.co.uk/2/hi/middle_east/4693091.stm
}

Geagea's2005 amnesty was granted just three months after a UN Fact Finding Mission to Lebanon presented a report to the Security Council stating that Lebanese officials "contributed to the propagation of a culture of intimidation and impunity" 29 .

Rafik Hariri's son Saad, the leader of the new majority in the parliament, who's closest local allies were ex-warlords Walid Joumblatt and Geagea, called for the establishment of an international tribunal back on October $23,2005^{30}$. It was just five months after Geagea's amnesty law was passed that Prime Minister Fuad Seniora's government requested the United Nations Security Council "to establish a tribunal of an international character (...) to try all those who are found responsible for the terrorist crime perpetrated against Prime Minister Hariri" and "to investigate the assassination attempts and assassinations and explosions that took place in Lebanon starting with the attempt on the life of Minister Marwan Hamade on 1 October $2004^{131}$.

Thus the same majority in the Lebanese Parliament passed an amnesty law for the murderer of one prime minister, but strongly supported the request to the United Nations to investigate and prosecute the case of the assassination of another prime minister. Yet, the Special Tribunal for Lebanon was established based on a document which specifically recalls Seniora's request $^{32}$, disregarding the fact that state-sanctioned impunity in Lebanon allowed targeted political assassinations to continue ${ }^{33}$.

Another kind of selective access to justice is in relation to the Lebanese civil war (1975-1990) and to the devastating July-August 2006 war which included a long list of serious human rights violations and brutal massacres, yet there was never any criminal investigation of these violations nor were those responsible brought to justice. Instead, in the case of civil war crimes, the Lebanese government passed a general amnesty Law in 1991 which granted amnesty for crimes committed by militias and armed groups before 28 March 1991. The amnestied leaders of militias that had "committed savage murders, often

\footnotetext{
${ }^{29}$ Fact Finding Mission headed by Peter Fitzgerald. Report S/2005/203 submitted to the SC on March 24, 2005 http://domino.un.org/unispal.nsf/0/ 79cd8aaa858fdd2d85256fd500536047? OpenDocument

${ }^{30} \mathrm{http}: / /$ english.aljazeera.net/focus/2009/03/20093152222705239.html

${ }^{31} \mathrm{~S} / 2004 / 783$. United Nations Security Council, 13 December 2005

${ }^{32}$ Security Council Resolution 1757 - May 30, 2007 http://www.stltsl.org/en/documents/un-documents/un-security-council-resolutions/securitycouncil-resolution-1757

${ }^{33}$ Knudsen, Page 19
} 
killing whole families and desecrating the victims",34 strongly promoted the establishment of an international tribunal to try those responsible for the assassination of Rafik Hariri.

There has been no plan to establish war crimes or human rights trials, and there are no policies for transitional justice mechanisms or a national reconciliation process ${ }^{35}$.

In 2006, Lebanon experienced the bombing of homes and hospitals, with hundreds of persons buried under the rubble. The Lebanon Higher Relief Council put the Lebanese death toll at 1,191 and estimated the number of Lebanese injured to be $4,409,15 \%$ of whom were permanently disabled ${ }^{36}$. United Nations personnel in Lebanon were also attacked and on 25 July 2006, four unarmed United Nations Truce Supervision Organization (UNTSO) peacekeepers ${ }^{37}$ were killed in an Israeli air strike on a UN observation post in Khiyam (Southern Lebanon). Here again, these crimes were not prosecuted and those responsible were not held accountable.

It may be argued that the bombing of Hariri's motorcade cannot be compared to armed forces' bombardment of civilian infrastructure and UN bases in Lebanon, and the ensuing slaughter. It should be noted that the right to access justice equally applies to victims of the bombardment of civil targets in Israel. However, it is access to justice for the victims that is at issue here. Neither Lebanese nor Israeli victims of the bloody events of 2006 have had access to international justice.

It may also be argued that the STL's selective justice should not imply denying access to justice in some cases as long as it's denied in other cases. This may be considered a valid argument if the selective process was not politically motivated and if the establishment of the STL complied with Lebanese constitutional provisions. The following section shows that this was not the case.

\section{COMPROMISING LEBANON'S SOVEREIGNTY}

UN Security Council Resolution 1664 (2006) requested Secretary-General Annan to negotiate an agreement with the Lebanese Government aimed at

\footnotetext{
${ }^{34}$ Ibid. Page 8

${ }^{35}$ Sriram, C. (2010) page 9.

${ }^{36}$ Lebanon Higher Relief Council (2007)."Lebanon Under Siege". March 5, 2007

${ }^{37}$ The four UNTSO victims are Hans-Peter Lang (Austria), Jarno Makinen

(Finland), Du Zhaoyu (China), and Paeta Derek Hess von-Kruedener (Canada)
}

establishing the STL, as mentioned earlier in this paper. The draft agreement approved by the Lebanese Cabinet on November 13, 2006, was signed in February 2007. After the signing, there were four months of stalemate during which parliament failed to convene. Thereafter, on May 30, 2007, the Security Council decided to overrule the Lebanese Constitution by considering the entry into force of the Agreement between Lebanon and the UN on establishing the Tribunal if the Lebanese parliament fails to approve it before June 10, 2007. It did, raising serious constitutional questions.

From a constitutional point of view, it should be noted that at the time the agreement was signed, there had been a devastating war (in July-August 2006) and six ministers, five of whom represented the total number of Muslim Shiite ministers, had resigned from the government. Paragraph $\mathrm{J}$ of The Lebanese Constitution's Preamble states "there is no constitutional legitimacy for any authority which contradicts the 'pact of communal coexistence'", which requires a representative presence of all major religious sects in the government.

The President of the Republic negotiates international treaties in coordination with the Council of Ministers. Treaties are to be ratified by the Parliament whenever the national interest and security of the state are involved, according to article 52 of the Constitution. However, the agreement to establish a Special Tribunal for Lebanon was neither negotiated by the President nor ratified by the Parliament. Therefore, the cabinet deliberations and its endorsement of the draft for the international agreement to establish the Special Tribunal for Lebanon "bypassed Lebanon's constitutional provisions" ${ }^{\prime 38}$. The President of the Republic, Emile Lahoud, denounced the Tribunal as "lacking any legal authority whatsoever" ${ }^{39}$, and the Speaker of Parliament, Nabih Berri, claimed that signing the agreement was unconstitutional since the government was considered unconstitutional after the resignation of the Muslim Shiite ministers.

Enforcement under Chapter VII (Article 2, paragraph 7) of the UN Charter, as an exception to the principle of national sovereignty (United Nations

\footnotetext{
${ }^{38}$ Amnesty International (2009) The Special Tribunal for Lebanon: Selective Justice? London: Amnesty International Publications. http://www.amnesty.org/ ar/library/asset/MDE18/001/2009/en/c9f6e5a4-688e-4bb6-983b-

096e099bf649/mde180012009en.pdf

${ }^{39}$ Bouhabib, M. A. (2010). Page 198
} 
Charter, Article 2, paragraph 1), was used by the Security Council to bypass Parliament. This approach differs from previous uses of Chapter VII to establish international tribunals. In the case of The International Criminal Tribunal for Yugoslavia and The International Criminal Tribunal for Rwanda, the use of Chapter VII was sparked by serious Human Rights violations and atrocities. This does not apply in the Hariri assassination case. Lebanon was not suffering from Human Rights violations that necessitate international intervention, and its parliament did not agree to permit such intervention in its internal affairs. However, it was argued that the United States, which has the strongest influence on the Security Council, politicized the judicial process $^{40}$ by pushing for the establishment of the STL under Chapter VII.

\section{Political Maneuver}

One third of the Security Council's members, including two permanent members, did not vote in favor of Resolution 1757. Nasser Abdul Aziz Al-Nasser, the Ambassador of Qatar, representing the only Arab state in the Council, expressed his country's support for the internal Lebanese constitutional process and stressed that the resolution which includes the statute of the Tribunal, "entailed legal encroachments" ${ }^{41}$.

Hasan Kleib representing Indonesia reminded the council that "Article 2 (7) of the United Nations Charter stressed that nothing contained in it would authorize the United Nations to intervene in matters that were essentially within the domestic jurisdiction of any State".

Dumisani Kumalo of South Africa considered it was not appropriate for the Council to bypass national procedures by imposing a Tribunal. China's Wang Guangya objected to interference in Lebanese internal affairs, and Russia's Vitaly Churkin considered the whole arrangement "dubious under international law"42.

From a political perspective, the UN decision to impose the STL on Lebanon in the absence of consensus may be perceived as "an extension of United States foreign policy, as the US President George W. Bush administration pushed for the tribunal

\footnotetext{
${ }^{40}$ Khairallah, D. (2008). The Hariri and Saddam Tribunals: Two Expressions of Tortured Justice. Contemporary Arab Affairs, Vol. 1, No. 4. Pp. 589-611

${ }^{41}$ Security Council, $5685^{\text {th }}$ meeting (S/PV.5685) May 30, 2007. http://daccessdds-ny.un.org/doc/UNDOC/PRO/N07/362/08/PDF/N0736208.pdf?

OpenElement

${ }^{42}$ Ibid
}

as part of its wider strategy to pressure Syria to abandon its alleged support for extremist groups across the region" ${ }^{43}$. France and the US also viewed the STL as an important tool to rid Lebanon of Syrian influence $^{44}$. In sum, the establishment of an international tribunal was a Western political maneuver to create a tool that can be manipulated to put pressure on Syria and Iran. The fact that STL indictments targeted pro-Iran and pro-Syrian Hezbollah officials was not a coincidence.

\section{Selective International Cooperation}

However, the Security Council failed to compel its members to cooperate with the STL. President Antonio Cassese admitted in February 2011 that "in the absence of binding UN Security Council resolutions to enforce cooperation (due to the peculiar legal position of the Special Tribunal), no solid legal framework has therefore been established for cooperation with States other than Lebanon" 45 . He also explained that "various states" refused to sign a cooperation agreement with the STL because of "domestic difficulties". Instead, these states have offered to cooperate "informally and on a case by case basis".

This provides opportunities for selective cooperation based on the political interests of these states and points that what applies to bypassing Lebanon's constitution may not apply to other members of the UN.

\section{STL's Unlimited Access to Official Records}

On June 5, 2009, Lebanese Minister of Justice Ibrahim Najjar (on behalf of the Lebanese Government) and STL Prosecutor Daniel Bellemare signed a Memorandum of Understanding (MoU) which granted international investigators access to unlimited official records. Paragraph 3 of the MoU states that the Lebanese Government will provide all necessary assistance to the STL office of the prosecutor with regard to access to all records, statements, material elements and evidence related to the crimes that fall

\footnotetext{
${ }^{43}$ Bosco, R.M. (2009), The Assassination of Rafik Hariri: Foreign Policy Perspectives. International Political Science Review, Vol. 30, No. 4, 349-361. Page 358.

${ }^{44}$ Khairallah (2008) claimed that "in the immediate wake of Hariri's assassination, nearly all Lebanese were in favor of an internationa investigation and tribunal to try those suspected of his murder. However, that unity faded away as Lebanese watched US officials intervene in their domestic affairs, manipulating the Tribunal to settle scores with Syrian and some Lebanese opponents." (page 606)

${ }^{45}$ Cassese, A. (2011) The Special Tribunal for Lebanon's Second Annual Report (2010-2011) submitted to the UN Secretary General, page 36 . http://www.stl-tsl.org/en/documents/president-s-reports-andmemoranda/second-annual-report-2010-2011
} 
under STL jurisdiction, and that are in the possession of Lebanese institutions, and to collect additional documents and information ${ }^{46}$.

In 2009, the Beirut office of the Special Tribunal for Lebanon's Prosecutor reportedly asked the Lebanese Ministry of Interior to provide an unlimited number of fingerprints of Lebanese citizens ${ }^{47}$. Bellemare's office also requested access to Lebanese civil status records, university student records and the database of the vehicle registration authority. International investigators further requested access to the records of telecommunication services.

Bellemare sent these requests to outgoing Prime Minister Saad Hariri in February 2011.

Hariri urged Minister of Interior Ziyad Baroud and Telecommunications Minister Charbel Nahhas to comply with the requests, which included allowing STL investigators to question ministry employees and obtain documents and telecommunications data.

Minister Nahhas told Speaker Berri on March 1, 2011 that "Bellemare had requested comprehensive information about telephone conversations among the Lebanese, including ministers and lawmakers, and that this violated the public freedom and eavesdropping law" $^{\text {"48. }}$. According to Nahhas, Bellemare had access to unofficial telecom data but he requested the Telecommunications Ministry to authorize access to official data so it could be used as evidence ${ }^{49}$. The defiant minister confirmed that he had ignored several requests from the STL because they "were contrary to Lebanese law as concerns the secrecy of phone records and immunity given to deputies and presidents" ${ }^{50}$.

\section{QUESTIONABLE STANDARDS}

The criminal investigation of the Hariri case, carried out by the Independent International Investigation Commission (UNIIIC) and reassigned to the Office of the UN Prosecutor after the launching of the STL in March 2009, used questionable professional and

\footnotetext{
${ }^{46}$ Memorandum of Understanding, June 5, 2009. Translated from Arabic by the author.

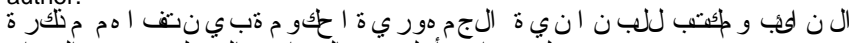

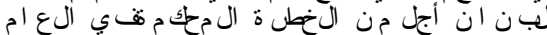

${ }^{47}$ This information was confirmed to the author by Minister of Interior Ziyad Baroud

${ }^{48}$ The Daily Star, March 2, 2011

${ }^{49}$ lbid.

${ }^{50}$ Interview with AFP March 2, 2011
}

ethical standards. Questions can also be raised concerning the wording of the indictment, the emphasis placed on telecommunication, selection of staff and impunity for arbitrary detention in the Hariri case.

\section{Detlev Mehlis's Breaches}

Berlin's prosecutor Detlev Mehlis was appointed on May 13, 2005 as commissioner for the UNIIIC. Mehlis was known for his controversial role in investigating the1986 Berlin terrorist attack on the Labelle Disco in Berlin. The methods he used in his investigations seemed highly controversial. A 1999 Amnesty International Report reads: "The trial of five people accused of a bomb attack continued in Germany. The prosecution claimed that the bombing of a West Berlin discotheque in 1986, apparently targeting US military personnel, had been carried out on direct orders from the Libyan intelligence service. In July a court in Berlin ruled that the confession of a former Libyan diplomat, Musbah 'Eter, was inadmissible because a prosecutor [Detlev Mehlis] had wrongly given the impression that he would be spared a life prison sentence if he confessed to a role in the bombing. A few days later the prosecution's challenge of the ruling failed. In August, the prosecution appealed again before a different chamber of the appeal court" ${ }^{21}$.

On August 25, 1998, German public television's ZDF reported that several leading suspects in the 1986 Berlin bombing "were being protected from prosecution by western intelligence services" ${ }^{52}$. These included "a group of terrorists led by Mahmoud Abu Jaber", a man allegedly involved in the preparation of the Labelle attack.

Abu Jaber's right-hand man, Mohammed Amairi was, according to his own lawyer Odd Drevland, an agent for the Israeli Mossad. After fleeing to Norway, Amairi was arrested and investigated. However, according to Drevland, the Mossad intervened and "everything changed" and Amairi was granted asylum. Berlin lifted the German police warrant against him ${ }^{53}$.

On October 20, 2005, the Security Council received Mehlis' first report on the Hariri assassination, in which the Commission concluded that "there is converging

\footnotetext{
${ }^{51} 1999$ Amnesty International Report: Libya - (January to December 1998). http://www.amnestyusa.org/annualreport.php?id=ar\&yr=1999\&c=LBY

${ }^{52}$ Ahmed, N.M.(October 28, 2005) UN's Mehlis Report Discredited International Espionage Over Syria? Media Monitors' Network http://americas.mediamonitors.net/content/view/full/22041 ${ }^{53}$ lbid.
} 
evidence pointing at both Lebanese and Syrian involvement in this terrorist act”,

However, evidence gathered by the Commission proved insufficient to support indictments of Syrian officials or anyone else for Hariri's murder. Mehlis expressed otherwise ${ }^{55}$. He had recommended the arrest of eight Lebanese. Among them were Former Director of General Security, Jamil Sayed, Director of Internal Security Forces, Ali El-Hajj, Head of Army Intelligence Raymond Azar, and Head of the Republican Guards, Mustapha Hamdan. The four remained behind bars for almost four years, until they were released on the grounds there was no credible evidence against them. Their imprisonment was considered "arbitrary detention" by the Geneva based UN Human Rights Council Working Group on Arbitrary Detention in its 2008 report to the UN General Assembly ${ }^{56}$.

In addition to his involvement arbitrary detention, Mehlis clearly violated Lebanese Law by publishing confidential judicial information. In the first report of the United Nations International Independent Investigative Commission (October 20, 2005) Mehlis published details of the investigations conducted by the Lebanese authorities prior to the arrival of international investigators. From page 16 to page 19 of the report made public immediately after it was presented to UN Security Council members, Mehlis published the names of more than 25 witnesses interviewed by Lebanese Judge Michel Abou Arraj (who resigned in March 2005 for unknown reasons). This was in clear violation of article 53 of the Lebanese Code of Criminal Prosecutions ${ }^{57}$ that is supposed to be respected by the UNIIIC according to article 2 and 4 of the Memorandum of Understanding, signed by Mehlis himself and Lebanese Minister of Justice Khaled Kabbani ${ }^{58}$.

Article 53 of the Lebanese Code of Criminal Prosecutions states: "The investigation shall remain confidential until such time as the case is referred to the trial court (...) Anyone who breaches the

\footnotetext{
${ }^{54}$ Report of the UNIIIC, October 19, 2005. Page 2, paragraphe 8 www.washingtonpost.com/wp-srv/world/syria/mehlis.report.doc

${ }^{55}$ Mehlis, in an interview for The Wall Street Journal, went on record in 2007 to say "When I left we were ready to name suspects" The Wall Street Journal, January 26, 2007 Interview with Detlev Mehlis by Michael Young. Republished on Now Lebanon on February 7, 2008: http://nowlebanon.com/NewsArchive Details.aspx? ID $=29771$

${ }^{56}$ Report of the Working Group on Arbitrary Detention, January 10, 2008, $\mathrm{A} / \mathrm{HRC} / 7 / 4$. Page 8

${ }^{57}$ Act No. 328 of 7 August 2001, amended by Act No. 359 of 16 August 2001

${ }^{58}$ Memorandum of Understanding between the Lebanese Government and the UNIIIC, June 16, 2005
}

confidentiality of the investigation shall be liable to prosecution". Mehlis' publication of the details of Abu Arraj's investigations also violated articles 55 and $42^{59}$. Moreover, Mehlis published statements of witnesses who gave testimony to the Commission and the Lebanese authorities before a witness protection program was functional. Among the statements published on page 12 is the statement of witness Gebran Tueini on June 25, 2005. The witness was assassinated on December 12 of the same year. Mehlis was not held accountable for failing to ensure his security as a witness ${ }^{60}$.

\section{Serge Brammertz's Term}

Mehlis resigned on December $15,2005^{61}$, and on January 11, 2006, he was replaced by Serge Brammertz. Unlike Mehlis, the new Commissioner refrained from making public the details of his work. No mention was made of witness testimonies implicating Lebanese or Syrian officials (or any other evidence of their complicity). Nor was Mehlis' conclusion on Syrian involvement in the assassination of Hariri repeated.

The Commission's mandate under Brammertz was widened $^{62}$, and it submitted six reports to the Security Council. The Commissioner underlined the fact that the inquiry only makes sense if it leads to a judicial process and that it is committed to a Special Tribunal. However, after two years of criminal investigations, the evidence gathered remained insufficient to issue indictments. The only substantial sign of progress in his investigation appeared in his third report in which Brammertz confirmed the theory of a suicide bombing in the assassination of Hariri ${ }^{63}$.

\section{Prosecutor Bellemare's Standards}

Brammertz stepped down on January 1, 2008 and was replaced by Daniel Bellemare.

\footnotetext{
${ }^{59}$ Translated from Arabic to English by the Special Tribunal for Lebanon and published on its website: http://www.stl-tsl.org/en/documents/relevant-law-andcase-law/applicable-law/lebanese-code-of-criminal-procedure

${ }^{60}$ Khairallah (2008) asked: "Has anyone heard of a criminal investigator, a district attorney or a special prosecutor making public the names and testimonies of witnesses he has heard, evidence he has collected, or strategies he is pursuing before the end of the investigation?". Page 591

${ }^{61}$ Shehadi, Nadim \& Wilmshurst, Elizabeth (2007), The Special Tribunal for Lebanon: The UN on Trial? Chatham House, Middle East/International Law Briefing Paper, MEP/IL BP 07/01. Page 5.

${ }^{62}$ The Commission would assist the Lebanese authorities in the investigation of 14 other terrorist attacks committed in Lebanon since October 2004, and of the assassination of the Minister for Industry, Pierre Gemayel, on 21 November 2006 and the Ain Alaq bombings of 13 February 2007. As well as investigating each attack, the Commission established possible linkages between them and the Hariri assassination.

${ }^{63}$ Fifth Report of The UN IIIC, September 25, 2006 http://www.stltsl.org/en/documents/un-documents/reports-of-the-uniiic/5th-report-of-theinternational-independent-investigation-commission-established-pursuant-tosecurity-council-resolutions
} 
UN Secretary General Ban Kin Moon named Bellemare $^{64}$ as UNIIIC Commissioner to be metamorphosed into the Prosecutor of the Special Tribunal upon its launch. In fact, the STL Prosecutor's work is supposed to be a continuation of UNIIIC's work, whereas Article 19(2) of the Agreement establishing the STL (Attached to Resolution 1757) states that it "shall commence functioning on a date to be determined by the Secretary General in consultation with the Government, taking into account the progress of the work of the UNIIIC".

The Prosecutor, and former UNIIIC Commissioner, were inconsistent in applying proper standards for the investigation. Bellemare openly visited Syria, held interviews with Hezbollah officials, and conducted investigative projects in Beirut's Southern suburbs as will be shown later in this paper. However, he and his staff were never reported to have visited Israel .Nor did they interview possible Israeli witnesses.

On August 8, 2010, in a two-hour long television appearance, Hezbollah's leader Hassan Nasrallah presented information pointing to Israel's possible involvement in the Hariri assassination. He said: "We have definite information on the aerial movements of the Israeli enemy the day Hariri was murdered. Hours before he was murdered, an Israeli drone was surveying the Sidon-Beirut-Jouniyeh coastline as warplanes were flying over Beirut (...) This video can be acquired by any investigative Commission to ensure that it is correct. We are sure of this evidence or else we would not risk showing it". Israel was quick to dismiss the allegation, despite the fact that the Israeli Army admitted in October 2010 that some of the information that Nasrallah revealed, concerning the aerial movements of the Israelis, was genuine ${ }^{65}$.

Nasrallah acknowledged that the images he showed during his television appearance and the information he provided were not conclusive evidence against Israel. However, there were no signs that STL Office of the Prosecutor has investigated or is even interested in investigating possible Israeli involvement in the Hariri assassination. Yet, Bellemare admitted interviewing Hezbollah officials. When asked "You have spoken to many Hezbollah officials. Did they ever mention the information Nasrallah came up with?" he said "No, it is

\footnotetext{
${ }^{64}$ November 16, 2007, The Secretary General SG/A/1109 http://www.un.org/News/Press/docs/2007/sga1109.doc.htm

${ }^{65}$ Yedihot Ahronot (November 5, 2010) http://www.ynetnews.com/ articles/0,7340,L-3980104,00.html
}

not related at all. They were interviewed like any other witnesses. It has nothing to do [with] what we saw from Mr. Nasrallah on TV"66.

In sum, the STL Prosecutor publicly revealed selective information about the identity of persons he interviewed. This may be considered at best noncompliance with the "highest standards of international criminal justice" stated in UNSC 1757, and at worst, a politically motivated breach of the confidentiality of the criminal investigation.

\section{Breaches of Confidentiality}

Further breaches of confidentiality concern information about the STL's indictment of Hezbollah adherents. This was leaked by Bellemare (or by his staff) to Rafik Hariri's son, Saad. Hezbollah leader Hassan Nasrallah said in July 2010, more than one year before the indictment was made public, that Hariri had told him that arrest warrants would soon be issued by the STL against members of his organization. Hariri claimed that, initially, three arrest warrants were expected to be issued, but by the end of 2010 , between 20 and 50 Hezbollah officials could be taken to court. During a personal meeting between the two men, Hariri expressed concern about the country's unity and said that he believed leaders of Hezbollah would not be affected by the arrest warrants but that only "rogue members" of the organization will be targeted. Nasrallah, for his part, dismissed the arrest warrants as "totally unacceptable" claiming that the court was being influenced by Israel.

Among those to be indicted, "according to the people briefed on it, is Mustafa Badreddine, a senior Hezbollah official and brother-in-law of the Hezbollah military commander Chief Imad Mughniyah, who was among the Federal Bureau of Investigation's mostwanted men before his assassination nearly three years ago" ${ }^{67}$. Mughniyah was also believed by Bellemare's investigators to have played a role in the car bombing that killed Hariri.

On May 23, 2009the German Der Spiege/ published a controversial report that included confidential UNIIIC records. The report's author, journalist Erich Folath, claimed that he "has learned from sources close to the

\footnotetext{
${ }^{66}$ NowLebanon Interview with Daniel Bellemare, August 31, 2010. Arthur Blok ${ }^{67}$ Solomon, J. \& Coker, M. (November 8, 2010) "U.N. Indictments Near in Lebanon Killing" The Wall Street Journal. http://online.wsj.com/article/ SB10001424052748703665904575600374005892944.html
} 
tribunal and verified by examining internal documents, that the Hariri case is about to take a sensational turn. Intensive investigations in Lebanon are all pointing to a new conclusion: that it was not the Syrians, but instead special forces of the Lebanese Shiite organization Hezbollah that planned and executed the diabolical attack. Tribunal prosecutor Bellemare and his judges apparently want to hold back this information, which they have been aware of for about a month"68. Bellemare refused to comment.

The actual STL indictment that was made public in August 2011 included information that was almost identical to a Canadian Media report (Canadian Broadcasting Corporation- CBC) of late $2010^{69}$. The report referred to investigators who worked with Bellemare and showed copies of confidential investigation records, claiming that "evidence gathered by Lebanese police and, much later, the UN, points overwhelmingly to the fact that the assassins were from Hezbollah, the militant Party of God (Hezbollah) that is largely sponsored by Syria and Iran. CBC News has obtained cell phone and other telecommunications evidence that is at the core of the case". The report concluded that telecommunications analysis led to "the single biggest breakthrough the commission had accomplished since its formation" ${ }^{70}$.

This additional breach of confidentiality by the STL Prosecutor's criminal investigators shows, here again, that the standards followed by the STL are questionable, especially since there was no sign of any investigation to hold accountable those who were responsible for the leaks.

\section{Breach of Ethical Standards}

As chief investigator at the STL Office of the Prosecutor, Michael Taylor enjoys access to a vast amount of data and official records from the Lebanese Government and its security and intelligence agencies, including personal status records, phone records, vehicle registration, and Lebanese University student records as mentioned earlier in this paper. However, his two male investigators who are part of Taylor's team, an Australian and a Frenchman, attempted on

\footnotetext{
${ }^{68}$ Der Spiegel (May 23, 2009) Folath, E. "New Evidence Points to Hezbollah in Hariri Murder". http://www.spiegel.de/international/world/0,1518,626412, 00.html

${ }^{69}$ MacDonald, N. (November 21, 2010) CBC Investigation: Who Killed Lebanon's Rafik Hariri? CBC News Special Report. http://www.cbc.ca/ world/story/2010/11/19/f-rfa-macdonald-lebanon-hariri.html ${ }^{70}$ lbid.
}

October 27, 2010 to collect further information about Hezbollah adherents from the office of gynecologist Iman Sharara. The office is located in the Hezbollah stronghold of Southern Beirut, and the investigators had arranged "an appointment with the purpose of examining the records of at least 14 people who had visited her clinic since 2003"71. Both the Lebanese Medical Association and the Ministry of Health were not approached and did not approve access to gynecological medical records. Yet Taylor's investigators decided to proceed in a clear violation of ethical and professional standards.

However, STL investigators were not allowed to complete their task as they were attacked by a number of women. The attackers snatched a briefcase that one of the investigators was carrying which contained a laptop and official STL documents. STL President, Judge Antonio Cassese, addressed the United Nations Secretary General, Ban Ki Moon and Lebanese Prime Minister, Saad Hariri on October 29, 2010, conveying "the Tribunal's great concern about the incident which took place in Beirut on 27 October." He added that the "incident will not be allowed to jeopardize the work of the Tribunal" ${ }^{72}$. However, Taylor's team did not attempt to visit the Sharara's office or any other location in Southern Beirut again. No one was arrested and the STL did not recognize or investigate this breach of ethical and professional standards, and its property was not returned.

\section{Questionable Evidence: Telecommunication}

In addition to the breaches of ethical standards, sources of doubt in the credibility of the Prosecutor's investigations also include the integrity of the collected data. Bellemare's investigators focused on collecting telecommunication data, which is highly controversial. The UNIIIC report released back on October 20, 2005, found that high-ranking members of the Syrian and Lebanese governments were involved in the Hariri assassination. The report based its findings on patterns of telephone calls between specific prepaid phone cards that connected prominent Lebanese and Syrian officials to events surrounding the crime. Bellemare apparently followed the same method to indict the four members of Hezbollah on January 2011. However, on

\footnotetext{
${ }^{71}$ Khatib, L. (October 29, 2010) "Hezbollah's Mobilization of the Multitudes" in Foreign Policy. http://mideast.foreignpolicy.com/posts/2010/10/29/hizbullah_s_ mobilization_of the multitudes

${ }^{72}$ STL Press Release October 29, 2010 http://www.stl-tsl.org/en/media/pressreleases/the-special-tribunal-for-lebanon-condemns-the-attack-against-staff
} 
October 22, 2010, the International Telecommunication Union (ITU) ${ }^{73}$ conference in Mexico, which is described as "ITU's top policy-making body that sets the general policies of the organization"74, had condemned "Israel's violation of Lebanon's telecommunications sector". The conference also stressed Lebanon's "complete right" to be compensated for the harms that have been inflicted on the telecommunications network". The condemnation came after extensive efforts by Lebanese Telecommunications Minister Charbel Nahhas to convince the 124 conference participants to condemn Israel and the outcome was 43 voting in favor, 23 against, and 57 abstentions. On November 23, 2010 Nahhas claimed during a press conference in Beirut that "Israel is continuing its widespread espionage penetration in Lebanon". A Lebanese technical expert working for the Lebanese Ministry of Telecommunications also explained how easily the Israelis infiltrated the telecom network, saying that the Israelis planted espionage devices in the Lebanese telecom antennae near the border with Lebanon ${ }^{75}$.

Since 2009, Lebanon has launched a nationwide crackdown on Israeli spy cells, arresting nearly 100 people, including members of security forces, the army, and telecommunications personnel, on suspicion of spying for Israel ${ }^{76}$.

However, the STL indictment emphasized telecommunication evidence, and according to paragraph 22 of the indictment, data of several cell phones used before Hariri's assassination revealed that they were active at the same location, on the same date, and within the same timeframe as other phones. The indictment also stated: "It is reasonable to conclude from these instances that one person is using multiple phones together when over a significant period, the patterns of use for each phone never deviate in an inexplicable manner, the phones are recorded by cell towers as being together over

\footnotetext{
${ }^{73}$ The International Telecommunications Union http://www.itu.int/ plenipotentiary/ 2010/index.html ITU's role as creator of the world's most universally recognized info-communications standards dates back to 1865 . ITU has been brokering industry consensus on the technologies and services that form the backbone of the world's largest, most interconnected systems. In 2007, ITU's Telecommunication Standardization Sector (ITU-T) produced over 160 new and revised standards (ITU-T Recommendations), covering core network functionality, broadband, and next-generation services like IPTV. http://www.dailystar.com.lb/article.asp?edition_id=1\&categ_id=3\&article_id=12 0740\#axzz16atK2jqa

${ }^{74}$ International Telecommunication Union's official website: http://www.itu.int/ plenipotentiary/2010/structure/index.html

${ }^{75}$ Annahar Daily Newspaper (In Arabic) - November 24, 2010 http://www. annahar.com/content.php?priority=1\&table=eco\&type=eco\&day=Wed

${ }^{76} \mathrm{~A}$ number of suspects have admitted their roles in helping Israel identify targets inside Lebanon, mostly belonging to Hezbollah, which were heavily bombed during the 2006 war.
}

extensive geographical areas, and the phones do not contact each other. This is called 'Co-Location"'77. Thereafter MP Hassan Fadlallah (Hezbollah), chair of the Telecommunications Committee at the Lebanese Parliament held a press conference during which he stressed that the circumstantial evidence presented by Prosecutor Bellemare, which is backed by cell phone data, was unreliable. "The scale of breaches in the telecoms network and Israeli capabilities in controlling it has led the network to be open for infiltration for years," said Fadlallah, adding that Israel could have easily tampered with such data ${ }^{78}$.

Several telecoms experts present at the conference showed a presentation of Lebanon's telecommunications system and presented several hypothetical cases in which data connected to cell towers and mobile phones could be altered by Israeli intelligence.

"Israel's infiltration of the sector has made the cell phone data [in the indictment] lose all of its credibility," said Imad Hoballah, the head of the Telecommunications Regulatory Authority. According to Hoballah, three Hezbollah members previously suspected of spying for foreign intelligence services were proved innocent after an investigation carried out by Lebanese Army intelligence. "It was found out that their phones were rigged by Israeli intelligence" ${ }^{\prime 79}$.

STL investigators placed emphasis on evidence related to telecommunication, despite the possibility of Israeli tampering with the data.

\section{Inadequate STL Selection of Staff}

STL staff breaches of professional and ethical standards also raise questions about the background of investigators and legal officers at the Office of the Prosecutor. In fact, the criteria used by the STL to employ staff seems questionable because, several employees were known for their lack of respect of the legal principle of presumption of innocence, and one senior official was under criminal investigation when he was appointed at the STL. Some of these employees were involved in the investigation and in putting together the indictment.

\footnotetext{
${ }^{77}$ http://www.stl-tsl.org/en/the-cases/stl-11-01/main/filings/indictments/ indictment-public-redacted-version

${ }^{78}$ The Daily Star, August 26, 2011 http://www.dailystar.com.lb/News/Politics/ 2011/Aug-26/Hezbollah-casts-doubt-on-telecoms-data.ashx\#axzz1W7rliPSC ${ }^{9}$ Ibid.
} 
Soon after the launch of the Tribunal in 2009, Dureid Bsherrawi was appointed legal officer at the STL's Office of the Prosecutor. In an article published in "An-Nahar" newspaper, Bsherrawi had expressed "fears of the possibility of failure in reaching the truth about Hariri's assassination, if some Security Council members strike a political deal with the Syrian regime at the expense of the International Tribunal for Lebanon" 80 . This implies that he was convinced of Syrian or pro-Syrian involvement in the assassination. Such expressions of prejudice should disqualify the candidate from becoming the legal advisor to the Office of the Prosecutor. Apparently not in this case.

The STL had also employed New South Wales (Australia) Police Commander Nick Kaldas as Chief Investigator at the Office of the Prosecutor, an appointment announced in mid-December 2008. In January 2004 Kaldas had been deployed by the Australian Federal Government to Iraq, initially as Senior Police Adviser for National Operations, then as Deputy Chief Police Adviser to the Coalition Provisional Authority $^{81}$ that was established as a transitional government following the invasion of Iraq by the United States and its allies and that was reported to be corrupt $^{82}$. He told the author during a meeting in The Hague on May 13, 2009 that he worked on creating a police intelligence force in $\mathrm{Iraq}^{83}$. In late 2005, he was redeployed to Iraq to carry out an assessment of the Iraqi Special Tribunal tasked with prosecuting Saddam Hussein.

What seems to be even more noteworthy about Kaldas, is that at the time he was appointed (December 2008), he was being investigated back in his homeland Australia in a case brought before Chief Justice Jim Spiegelman ${ }^{84}$ concerning allegations of withholding information from the Court in the investigation of the murder of Labor MP John Newman in 1994. Although Kaldas was found innocent on April 16, 2009, the fact that he was appointed Chief Investigator at the STL when he was still under judicial investigation points to questionable standards of employment and a serious

\footnotetext{
${ }^{80}$ Bsherrawi, D. (2007) Annahar Daily Newspaper, December 27, 2007 (translated from Arabic by the author)

${ }^{81} \mathrm{http}: / / \mathrm{www}$.securityexpo.com.au/conference. asp? $\mathrm{id}=50 \#$

${ }^{82}$ Macrae, C. \& Fadhil A. (March 20 2006) Iraq was awash in chash. We played football with bricks of $\$ 100$ bills. In The Guardian. http://www.guardian.co.uk/ world/2006/mar/20/usa.iraq

${ }^{83}$ Interview published in Al-Akhbar Lebanese Daily. No. 817. May 13, 2009 page 6 . (translated by the author)

${ }^{84}$ Pelly, M. \& Hohenboken, A. (June 7, 2008) "Top Cop Nick Kaldas Named in Report on Phuong Ngo". The Australian.http://www.theaustralian.com.au/news/ top-cop-named-in-report-on-ngo/story-e6frg6o6-1111116564792
}

breach of the "highest standards of International criminal justice".

Kaldas resigned in February 2010 and was replaced by New Scotland Yard's former Head of Intelligence on counter terrorism, Michael Taylor. Chief Investigator Michael Taylor played a central role in putting together the STL indictments. Taylor had served as "Head of Intelligence, Counter-Terrorism Command, at New Scotland Yard from March 2004 to August 2006"85.

\section{Questionable Rules of Procedures and Evidence}

Although most of STL's rules of procedures and evidence are based on the rules of other international criminal tribunals, some of the amendments to these rules seem politically motivated.

The Judges of the Special Tribunal for Lebanon met in a plenary session in November 2010 to consider proposed amendments to the STL Rules of Procedure and Evidence adopted on March 20, 2009 (previously amended twice - on June 10, 2009 and October 30, 2009). Amongst the most important amendments introduced in November 2010 were changes to the rules "governing the service of an indictment by detailing the practical steps that must be taken after the confirmation of an indictment, in particular regarding the start of in-absentia proceedings" 86 . The new framework allegedly creates "more legal certainty for accused and other parties in the proceedings" ${ }^{17}$. The Judges also clarified the admissibility of written statements by witnesses unable to come and testify "for good reasons". These amendments may be seen as a political response following Nasrallah's declaration that he did not recognize the STL's legitimacy ${ }^{88}$ and any indictments of Hezbollah members would have to be tried in absentia. However, other STL rules raise more questions about the transparency and adequacy necessary for the attainment of justice. Paragraph F, under rule 118, states that "if the Prosecutor calls a witness to introduce in evidence any information provided under this Rule, neither the Pre-Trial Judge nor the Trial Chamber may compel that witness to answer any question relating to the information or its

\footnotetext{
${ }^{85}$ Special Tribunal for Lebanon Appoints New Chief of Investigations, March 12 2010http://www.stl-tsl.org/en/media/press-releases/special-tribunal-forlebanon-appoints-new-chief-of-investigations

${ }^{86}$ STL Press Release November 19, 2010 http://www.stl-tsl.org/sid/214 ${ }^{87}$ Ibid.

${ }^{88}$ The New York Times quoting Associated Press (September 3, 2010) "Lebanon: Hezbollah Chief Rejects Demand From U.N. Prosecutor". http://www.nytimes.com/2010/09/04/world/middleeast/04briefsHEZBOLLAH.html?_r=2\&partner=rss\&emc=rss
} 
origin if the witness declines to answer on grounds of confidentiality" 89 . This represents a clear breach of the basic guarantees for the attainment of justice because Judges should have the authority to question the source of "evidence" collected by the prosecutor and presented in court.

Rule 117 allows non-disclosure of information to protect "security interests of states and other international entities". This rule states that where the disclosure of information "may affect the security interests of a State or international entity, the Prosecutor may apply ex parte to the Pre-Trial Judge sitting in camera for an order to be relieved of his obligation to disclose in whole or in part". Rule 118 also expands on this by noting that "where the Prosecutor is in possession of information which was provided on a confidential basis and which affects the security interests of a State or international entity or an agent thereof, he shall not disclose that information or its origin without the consent of the person or entity providing the information". The rules also grant the prosecution the opportunity to select the presentation format of witness statements: "the Prosecutor shall take reasonable steps to obtain the consent of the provider to (i) disclose that information or the fact of its existence to the accused or (ii) provide an alternative form of disclosure such as: identification of new similar information; provision of the information in summarized or redacted form; or stipulation of the relevant facts. If the Prosecutor obtains such consent, the Prosecutor shall make the disclosure that has been consented to without delay". Hence, once the consent of the witness is secured the prosecution is granted an opportunity to rephrase his or her statements and present it in a way that may limit the defense's prospect for efficient crossexamination ${ }^{90}$.

\section{Indicting Nasrallah}

Bellemare's indictment of certain members of Hezbollah, not its leadership or any of its officials has been part of Western official statements about Lebanon. Former British Ambassador to Lebanon Frances Guy emphasized that "the tribunal is not going to accuse any sect or any party; it is going to accuse

\footnotetext{
${ }^{89}$ STL Rules of Procedures and Evidence are available on the STL website: http://www.stl-tsl.org/x/file/TheRegistry/Library/BackgroundDocuments/ RulesRegulations/RPE_EN_November\%202010.pdf

${ }^{90}$ Nashabe, O. (February 2011). The Special International Tribunal for Lebanon: Politics and the Law. Socialist Lawyer, No. 57. London: Haldane Socaity. Pp.24-27.
}

some individuals"91. French Minister of Foreign Affairs Michèle Alliot-Marie was even more explicit. She announced on January 4, 2011, that "Hezbollah has members who were voted into Government institutions (...). If persons are suspected by the Special Tribunal for Lebanon, they will be suspected as persons not as representatives of a party or of a community" ${ }^{\prime \prime 2}$. However, a review of the Tribunal's Statute shows that the leadership of Hezbollah is likely to be indicted if some of its members are. Legally, individual members come within the structure of command of the organization.

The Tribunal's Statute states clearly: "with respect to superior and subordinate relationships, a superior shall be criminally responsible for any of the crimes (...) committed by subordinates under his or her effective authority and control, as a result of his or her failure to exercise control properly over such subordinates, where: (a) The superior either knew, or consciously disregarded information that clearly indicated that the subordinates were committing or about to commit such crimes; (b) The crimes concerned activities that were within the effective responsibility and control of the superior; and (c) The superior failed to take all necessary and reasonable measures within his or her power to prevent or repress their commission or to submit the matter to the competent authorities for investigation and prosecution"93.

As Salim Ayyash, Mustapha Badreddine, Hussein Oneissi \& Assad Sabra were accused of committing the crime, it would be argued that their superiors failed to realize that they were about to commit such a crime, especially since more than two tons of explosives had to be transported and placed in a vehicle, and a large number of people had to be mobilized to collect information about the target's transportation and daily schedule.

Hezbollah is considered "a clandestine, impenetrable and paranoid organization in which the central element of security is the recruitment of Shia

\footnotetext{
${ }^{91}$ Interview published in the Daily Star. http://www.thefreelibrary.com/Guy\%3A+ Tribunal+is+an+'opportunity'+to+see+how+justice+should+operate.a0244137604

92، Le Hezbollah a des élus dans les institutions, ce qui prouve le fonctionnement des institutions. Si des personnes sont mises en cause devant le TSL, elles le seront en tant que personnes et non comme représentantes d'un parti ou d'une communauté". http:/www.diplomatie.gouv.fr/fr/ ministere_817/ministre-etat-les-ministres_818/michele-alliotmarie_20431/presse-media_20436/entretien-michele-alliot-marie-avec-20minutes-04.01.11_88727.html\#so_1

${ }^{93}$ The Statute of the Special Tribunal for Lebanon - Attached to SC Resolution 1757 (May 30, 2007) Article 3, paragraph 2
} 
cadres" ${ }^{\prime 94}$. Some American observers even claim that it "established a sophisticated intelligence apparatus that

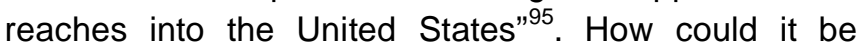
argued that the leadership of such an allegedly sophisticated organization would not be suspected of having information about the assassination of Hariri when some of its members are indicted?

\section{Impunity for Arbitrary Detention}

The Lebanese officers incarcerated for almost four years $^{96}$ (Generals Jamil Sayed, Ali El-Hajj, Raymond Azar, and Mustapha Hamdan) have so far been denied access to justice with regard to the persons responsible for their arbitrary detention. In one example, the Office of the Prosecutor continues to create obstacles to giving Jamil Sayed access to some of the documents in its possession ${ }^{97}$. Such documents would allow his lawyers to proceed with court cases to prosecute those responsible of arbitrary detention. The documents Sayed has requested are:

A certified copy of the records of Sayed's complaints that were forwarded to the STL by the Lebanese authorities on March 1, 2009;

A certified copy of the records of the witness statements which allegedly implicated Sayed directly or indirectly in the Hariri assassination;

The reports provided to the Lebanese Prosecutor relating to the assessment of the above-mentioned statements and in particular the reports by Brammertz provided on December 8, 2006;

the opinion of Bellemare regarding the detention of Sayed and the other detainees, which was allegedly forwarded to the Lebanese Prosecutor General; and

\footnotetext{
${ }^{94}$ Jaulmes, A (September 17, 2009) Beyrouth, nid d'espions. Paris : Le Figaro http://www.lefigaro.fr/international/2009/09/14/01003-20090914ARTFIG00414beyrouth-nid-d-espions-.php

${ }^{95}$ Burton, F, Stewart F. (2007) Hezbollah: Signs of a Sophisticated Intelligence Apparatus. Stratfor Global Intelligence http://www.stratfor.com/weekly/ hezbollah_signs_sophisticated_intelligence_apparatus

${ }^{96}$ Report of the Working Group on Arbitrary Detention, January 10, 2008, $\mathrm{A} / \mathrm{HRC} / 7 / 4$. Page 8

${ }^{97}$ Head of Prosecutions in the STL Office of the Prosecutor, Daryl Mundis, representing Bellemare, refused to answer questions addressed to him by the Pre-Trial Judge Daniel Fransen during a public hearing on July 13, 2010. STL transcript: http://www.stl-tsl.org/en/the-cases/in-the-matter-of-el-sayed/main/ transcripts/transcript-hearing-of-13-july-2010 .Bellemare also waited until one day before the due date set by Fransen to answer the questions in writing to appeal the decision made by the pre-trial judge on September 17, 2010.
}

any other piece of evidence necessary for prosecution of the offences that the president (Cassese) might possess ${ }^{98}$.

Bellemare's office argued that most of these documents are supposed to remain confidential.

In essence, those responsible for the arbitrary detention of persons in the Hariri case remain free from accountability thanks to an International tribunal that was created, allegedly, to "end impunity" ${ }^{19}$, especially since the four officers remained incarcerated even after the STL was launched on March 1, 2009.

\section{Wording of the Indictment}

The wording of parts of the indictment may be interpreted as politically motivated and therefore lacking impartiality. An example of this bias appears in paragraph 59, where Bellemare states that "all four accused are supporters of Hezbollah, which is a political and military organization in Lebanon. In the past, the military wing of Hezbollah has been implicated in terrorist acts"100. Bellemare, who stresses the "experience, training and affiliation"101 of the indicted persons with Hezbollah, does not offer a reference supporting his assertion that Hezbollah was involved in terrorism, and, so far, no international judicial body has issued a decision describing Hezbollah as a terrorist organization. In fact, there is no international consensus surrounding Hezbollah or its military wing's "terrorism" status, and the United Nations does not recognize Hezbollah as a terrorist organization. Several countries, including the United States, Israel, and Canada have officially labeled the group as a terrorist organization - though, notably, the European Union has not. Bellemare seemingly chose

\footnotetext{
${ }^{98}$ According to paragraph 7 of Judge Daniel Fransen's "Order Relating to the Jurisdiction of the Tribunal to Rule on the Application by Mr. El Sayed dated 17 March 2010 and Whether Sayed has Standing Before the Tribunal" dated September 17, 2010. http://www.stl-tsl.org/en/the-cases/in-the-matter-of-elsayed/main/filings/orders-and-decisions/pre-trial-judge/order-relating-to-thejurisdiction-of-the-tribunal-to-rule-on-the-application-by-mr-el-sayed-dated-17march-2010-and-whether-mr-el-sayed-has-standing-before-the-tribu

${ }^{99}$ Wetzel \& Mitri (2008) argue that the STL "breaks new ground as an international effort to specifically end impunity for terrorist acts". Wetzel, J.E. \& Mitri, Y. (2008) The Special Tribunal for Lebanon: A Court "Off the Shelf" for a Divided Country. The Law and Practice of International Courts and Tribunals 7 (2008) 81-114. Martinus Nijhoff Publishers. http://eprints.lincoln.ac.uk/3047/1/ Wetzel\%26Mitri_Special_Tribunal_Lebanon_LPICT_7(2008).pdf

Al Sharq al-Awsat newspaper journalist, Raghida Bahnam asked STL President Antonio Cassese on April 28, 2009 "This tribunal has been set up to put an end to the impunity of political assassination in Lebanon, do you think it will achieve this?", he reportedly answered: "Yes, I am confident". (translated from Arabic by the author) http://www.aawsat.com/english/news.asp?section= 3\&id $=16550$

${ }^{100} \mathrm{http}: / / w w w . s t l-t s l . o r g / e n / t h e-c a s e s / s t l-11-01 /$ main/filings/indictments/ indictment-public-redacted-version

${ }^{101}$ Ibid.
} 
to include his personal political opinion and perhaps the views of some of his colleagues in an international indictment.

\section{CONCLUDING REMARKS}

The United Nations International Independent Investigative Commission and the Special Tribunal for Lebanon were established by the UN Security Council to investigate the assassination of former Prime Minister Rafik Hariri and others, and, supposedly, to achieve justice. However, limitations to the STL's jurisdiction showed signs of politically motivated selective justice. The STL has not addressed the larger legacy of political assassination and war crimes that have marked Lebanon's past. As such, this paper suggests that it is therefore unlikely to contribute to ending impunity in Lebanon.

This paper also argued that the establishment of the STL was a compromise to Lebanon's sovereignty because the UNSC bypassed Lebanon's constitutional provisions.

High-level Media leaks about the criminal investigation, further undermines the credibility of the Tribunal. As for its rules of procedures and evidence, they may allow disregarding the manipulability of some sources of evidence, not least from telecommunications.

The UNIIIC and the STL investigators did not look into possible Israeli involvement in the Hariri assassination, and the indictment does not seem to be based on persuasive evidence because it is based on telecommunication data that may have been altered by Israeli intelligence and because part of its wording seems politically motivated.

Finding effective remedies for the structural and procedural ills of the STL is a major challenge. It may require Lebanese minimum consensus on the separation between attaining justice and political interests.

Stretching the STL's jurisdiction to include other serious crimes that were committed since 2005 may contribute to improving its local reputation as a judicial mechanism. As for the atrocities of the civil war, establishing a truth and reconciliation commission may be necessary especially since thousands are still missing. However, discussing these matters, the agreement to establish the STL and its rules of procedures and evidence, in the Lebanese parliament may be essential to consolidate local ownership of justice.

Concerning the STL's procedural ills and in order to make sure it functions according to the highest standards of international criminal justice, an independent monitoring mechanism should be suggested, and modes of accountability for judges, prosecutors, legal officers and defense counsels have to be defined.

The search for remedies requires further criminal justice, Law and political science research, and broad discussions among scholars, legal experts and politicians.

Such research is much needed because The STL's political context and its dubious procedures, serve neither justice nor ending impunity in Lebanon, but rather threaten the very basis of the Lebanese state that is built on local consensus.

\section{APPENDIX}

\section{Chronology of Events}

\begin{tabular}{|c|c|}
\hline $1975-1990$ & Lebanese civil war \\
\hline March 28, 1991 & $\begin{array}{l}\text { General Amnesty Law for crimes committed } \\
\text { during the war }\end{array}$ \\
\hline October 1, 2004 & $\begin{array}{l}\text { Assassination attempt of Minister Marwan } \\
\text { Hamaded }\end{array}$ \\
\hline $\begin{array}{l}\text { February } 14, \\
2005\end{array}$ & $\begin{array}{l}\text { Assassination of former Prime Minister Rafik } \\
\text { Hariri }\end{array}$ \\
\hline $\begin{array}{l}\text { February } 15, \\
2005\end{array}$ & $\begin{array}{l}\text { The UN Security Council issues a Presidential } \\
\text { Statement considering the assassination a } \\
\text { terrorist crime }\end{array}$ \\
\hline
\end{tabular}

April 7, $2005 \quad$ The UN Security Council sets up the International Independent Investigation Commission (UNIIIC)

May 13,2005 Appointment of Detlev Mehlis as UNIIIC Commissioner

June 2, 2005 Assassination of journalist Samir Kassir

June 21, 2005 Assassination of politician George Hawi

June 25, 2005

MP Gebran Tueini's witness statement to the UNIIIC

July 18,2005

Lebanese Amnesty Law for Samir Geagea who was found guilty of assassinating PM Rashi Karameh in 1984

August 30, 2005 Four Lebanese Army and Police Generals are arrested based on the UNIIIC's recommendation

October 21, 2005

UNIIIC Commissioner Detlev Mehlis submits first report to the UN Security Council

October 23, 2005

Saad Hariri, Rafik Hariri's son, calls for the establishment of an international tribunal.

December 12, Assassination of MP Gebran Tueini 
December 15, UNIIIC Commissioner Mehlis resigns 2005

January 11, Serge Brammertz replaces Mehlis as UNIIIC 2006 Commissioner

March 29, 2006 UN Security Council Resolution 1664

July 12 - August Israel's war on Lebanon

14,2006

July 26, 2006

Four UNTSO international observers killed by Israeli bombing

November 13 2006

Lebanese Cabinet approves draft mandate of the international tribunal

May 30, 2007

UN Security Council resolution 1757 authorizes the establishment of the Special Tribunal for Lebanon under UN Charter's Chapter VII to try those responsible of the Hariri assassination and other related crimes, if the Lebanese Government fails to sign the agreement to establish the STL.

June 10, 2007 The Lebanese Government does not sign the agreement to establish the STL

December 27 2007

March 2008

Assassination of Pakistan's former PM Benazir Bhutto

The UN's Working Group on Arbitrary Detention criticizes the Lebanese government's continued detention of the four Generals without charge and calls their detention "arbitrary" and "unjust".

March 1, 2009 The Special Tribunal on Lebanon starts functioning in The Hague (Netherlands)

April 29, 2009 Pre Trial Judge Daniel Fransen orders the release of four Lebanese generals held without charge since 2005.

May 23, 2009 Der Spiegel publishes leaked international investigation documents

October 27, 2010

November 21, 2010

January 17 2011

March 11, 2011

May 6, 2011

June 28, 2011

July 29, 2011

August 17, 2011 STL Indictment published

\section{REFERENCES}

Addis, C.L. \& Blanchard, C.L. (2010) Hezbollah: Background and Issues for Congress Congressional Research Service. http://www.fas.org/sgp/crs/mideast/R41446.pdf

Agreement between the United Nations and the Lebanese Republic on the establishment of the Special Tribunal for Lebanon, (Annex to SC Resolution 1757 - S/RES/1757 (2007)

Amnesty International (2009), The Special Tribunal for Lebanon: Selective Justice? Amnesty International Publications
Annan, Kofi, Letter dated 24 March 2005 from the Secretary-General to the President of the Security Council http://domino.un.org/unispal.nsf/0/79cd8aaa858fdd2d85256f d500536047?OpenDocument

Ban Ki Moon (2009). Fourth report of the Secretary-General submitted pursuant to Security Council resolution 1757 (2007) February 24, 2009 (S/2009/106) http://www.stltsl.org/en/documents/un-documents/un-secretary-generalreports/fourth-report-of-the-secretary-general-submittedpursuant-to-security-council-resolution-1757

Ben-Yehuda, N. (1997). Political Assassination Events as a CrossCultural Form of Alternative Justice. International Journal of Comparative Sociology 38(1-2): 25-47 http://dx.doi.org/10.1177/002071529703800103

Bosco, R.M. (2009), The Assassination of Rafik Hariri: Foreign Policy Perspectives. International Political Science Review, Vol. 30, No. 4, 349-361. http://dx.doi.org/10.1177/0192512109342521

Bouhabib, M. A. (2010) Power and Perception: The Special Tribunal for Lebanon. Berkeley Journal of Middle Eastern Islamic Law. Vol. 3 No.1, 173-20.

Cerone, J. (2009) US Attitudes toward International Criminal Courts and Tribunals, in The Sword and the Scales, Edited by Romano, C., New York: Cambridge University Press

Fitzgerald, Peter (2005) Fact Finding Mission Report. Report S/2005/203 submitted to the UN Security Council on March 24, 2005

Haven, M.C., Leiden C. \& Schmitt, K. M (1970) The Politics of Assassination (Englewood Cliffs, NJ: Prentice Hall

Herman, Edward S. (2007) The Hariri Special Court v/s the Imminent U.S. Attack on Iran. Z Magazine, Global Research.

Khairallah, D. (2008). The Hariri and Saddam Tribunals: Two Expressions of Tortured Justice. Contemporary Arab Affairs, Vol. 1, No. 4. Pp. 589-611. http://dx.doi.org/10.1080/17550910802391118

King-Irani, Laurie (May, 31, 2007) Tribunals, Trials and Tribulations in Lebanon? Electronic Lebanon, http://electronicintifada.net/v2/article6986.shtml

Knudsen, A. (2010), Acquiescence to Assassinations in Post-Civil War Lebanon? Mediterranean Politics, Vol. 15, No. 1, 1-23 http://dx.doi.org/10.1080/13629391003644611

Mehlis, D. (2005) United Nations Independent International Investigation Commission (UNIIIC) First Report (2005) October 19

Mugraby, M. (2008)'The Syndrome of One-Time Exceptions and the Drive to Establish the Proposed Hariri Court', Mediterranean Politics, 13:2, 171-194. http://dx.doi.org/10.1080/13629390802127513

Nashabe, O. (February 2011). The Special International Tribunal for Lebanon: Politics and the Law. Socialist Lawyer, No. 57. London: Haldane Socaity. Pp.24-27.

Security Council, 5685 ${ }^{\text {th }}$ meeting (S/PV.5685) May 30, 2007. http://daccess-ddsny.un.org/doc/UNDOC/PRO/N07/362/08/PDF/N0736208.pdf ?OpenElement

Seale, P. (2007) Chirac, Hariri, and the International Court. Globa Policy Forum, Middle East Online http://www.globalpolicy.org/component/content/article/168/29 018.html

Shehadi, N. \& W., Elizabeth (2007), The Special Tribunal for Lebanon: The UN on Trial? Chatham House, Middle East/International Law Briefing Paper, MEP/IL BP 07/01

Sriram, C. (2010). Unfinished Business: Peacebuilding, Accountability, and Rule of Law in Lebanon. SOAS School of Law Legal Studies Research Paper Series. Research Paper No.16/2010.

STL Public Redacted Version of the June 10, 2011 Indictment http://www.stl-tsl.org/en/the-cases/stl-11- 
01/main/filings/indictments/indictment-public-redactedversion

The STL Rules of Procedure and Evidence, November 29, 2010. http://www.stl-tsl.org/en/documents/rules-of-procedure-andevidence/rules-of-procedure-and-evidence-29-november2010

UN News Center (December 18, 2006), UN probe into murder of former Lebanese leader nears sensitive stage.http://www.un.org/apps/news/story.asp?NewsID=2103 $4 \& \mathrm{Cr}=$ leban $\& \mathrm{Cr} 1=$

Wetzel, J.E. \& Mitri, Y. (2008) The Special Tribunal for Lebanon: A Court "Off the Shelf" for a Divided Country. The Law and
Practice of International Courts and Tribunals 7 (2008) 81114. Martinus Nijhoff Publishers http://eprints.lincoln.ac.uk/3047/1/Wetzel\%26Mitri_Special_Tr ibunal Lebanon LPICT 7(2008).pdf http://dx.doi.org/10.1163/157180308X311110

Wierda, M., Nassar, H. \& Maalouf, L. (2007). Early Reflections on Local Perceptions, Legitimacy, and Legacy of The Special Tribunal for Lebanon. Journal of International Criminal Justice. Vol. 5 No. 5. pp. 1065-1081. http://dx.doi.org/10.1093/jicj/mam072

Received on 01-09-2012

DOI: http://dx.doi.org/10.6000/1929-4409.2012.01.23

(C) 2012 Omar Nashabe; Licensee Lifescience Global.

This is an open access article licensed under the terms of the Creative Commons Attribution Non-Commercial License (http://creativecommons.org/licenses/by-nc/3.0/) which permits unrestricted, non-commercial use, distribution and reproduction in any medium, provided the work is properly cited. 